\title{
CATHERINE MILLET Y LA NUEVA LITERATURA ERÓTICA FRANCESA
}

\author{
Carmen Ramírez Gómez \\ Universidad de Sevilla
}

\begin{abstract}
The term "erotism" isalways controversial, because of its carnal purpose and mercurial history. From an aesthetic perspective, literature and erotism mean how to express the desire, how to view and to listen to the body, its tale and its picture. This paper focuses on the erotic French literature written by women. We analyse the e questions in the novel of Catherine Millet, The Sexual Life of Catherine M., that has represented a new way of writing erotic literature.
\end{abstract}

\section{INCIPIT.}

El término "erotismo" se salva difícilmente de la polémica a la que por otra parte le condenan un destino naturalmente carnal y una memoria inevitablemente lubricada. Tratar de literatura y de erotismo significa acercarse desde una perspectiva estética a cómo decir el deseo, cómo mirar la anatomía y cómo escuchar el relato del cuerpo. Cuando se enmarca en un registro femenino se agudizan los índices de impacto pues a nadie escapa que en la literatura erótica, por defecto, sus autores, lectores y editores han sido reservados largo tiempo a la empresa masculina, y por exceso, su objeto predilecto ha anexionado los territorios de la anatomía femenina y su legendaria versatilidad. Este estado de cosa empieza a cambiar en el siglo XX que ha supuesto en todos los dominios públicos y privados una irreversible y progresiva visibilidad de la mujer, tendencia ésta que afecta también el ámbito de la creación y de la literatura, y alcanza especial relevancia en las letras eróticas, en el triple proceso de creación, producción y recepción.

En este contexto, destacaremos dos textos narrativos de interés ayer y hoy, escritos por autoras y mujeres singulares que han contribuido con un especial significado a la elaboración de esta página literaria de antiguos orígenes, y de renovado formato por la recién incorporada identidad femenina, y por impulsar un viraje en el modo, en el fondo y en la forma que propiciaron conjuntamente con otras escritoras. Acotan este propósito la Histoire d'O de Pauline Réage y La vie sexuelle de Catherine M. de Catherine Millet', considerando que entre ambas, y ulteriormente, se ha dispuesto la emergente literatura erótica femenina. Y si Millet engarza uno de los postreros eslabones en la cadena del Eros literario femenino contemporáneo, su obra ha supuesto amén de un punto de llegada - todo

\footnotetext{
'La primera fue publicada por Jean-Jacques Pauvert en 1954, y la segunda, por Seuil en 2001.
} 
acto de creación resuma en sí mismo un arribo-, un umbral de partida no sólo para proponer una revisión, sino también para plantear una reflexión en torno al estado de la cuestión.

Aunque encontramos desde principios del siglo XX textos eróticos de autoría femenina ${ }^{2}$, el erotismo se instala en las librerías francesas a partir de los años 1970, coincidiendo con el espaldarazo de esta literatura cuyo desarrollo atraviesa las tres últimas décadas del siglo XX, sin decrecer en los albores del siglo XXI. Proliferan escritoras y títulos ${ }^{3}$ : Contes pervers, Régine Desforges (1980), Les Vaisseaux du cour, Benoîte Groult (1990), La Femme de papier, Françoise Rey (1990), Les Travaux d'Hercule, Camille Laurens (1994), Des Désirs et des Hommes, Françoise Simpère (2000), Lettres du désir, Claire Yenidem, (2000), Se perdre, Annie Ernaux (2001), Ma vie douce, Alina Reyes (2001), L'Homme abandonné, Ariane Larsen (2002), Lettres à un monsieur, Sylvie Bourgeois (2003)... Editoriales y librerías ${ }^{4}$ asisten y participan a la introducción masiva de la escritura erótica al femenino, no siempre de la mejor calidad ${ }^{5}$, incluso a menudo constituye una simple respuesta a los dictados de una nueva erotomanía femenina. El perfil del lector también ha variado en consonancia con la propia evolución del escritor, y a veces al hilo del movimiento de la sociedad, y de la impronta que supone la orientación del mercado editorial.

La incorporación de las escritoras al género licencioso lleva aparejado naturalmente un nuevo consumidor: si antes el lector era el gran comprador de esta literatura de la carne, el consumo de cuentos, relatos, novelas o cómics, también se ha feminizado. La empresa editorial una vez más adapta el canon a las necesidades del mercado, y condiciona el gusto al mejor postor. Se opera además un curioso deslizamiento junto a la escritura propiamente

\footnotetext{
${ }^{2}$ Sin ser completa ni exhaustiva, la lista incluiría al menos a las autoras y a las obras siguientes: Les Amantes féminines, Adrienne Saint-Agens (1907), L'Ingénue libertine, Colette (1908), Les Caprices du sexe, Renée Dunan (1938), Histoire d'une petite fille, Laure (1943), Mémoire d'une gouvernante, Paulette Verger (1928-1957), Le Repos du guerrier, Christiane Rochefort (1958), Emmanuelle, Emmanuelle Arsan (1959), Thérèse et Isabelle, Violette Leduc (1966), Les Guerillères, Monique Witting (1969), Les Dix japonais, Léone Guerre (1970), Les Pâles et fiévreux après-midi des villes, Annie Lebrun (1973), Alice's paradis (Eros zéro), Janine Aeply (1972), Mémoires d'une liseuse de draps, Belen -Nelly Kaplan- (1974), Et délivrez-nous de l'amour, Suzanne Brögger (1978), L'Or des Chambres, Françoise Lefèvre (1975), Dire nos sexualités, Xavière Gauthier (1976), Pièces d'astrologie sexuelle, Krista Lenk (1976), Lola, Régine Desforges (1979).

${ }^{3}$ Se trata de una lista meramente orientativa en tanto esta producción es cuantiosa, diversificada y contínua.

${ }^{4}$ Cabe destacar La Musardine, editorial y librería, las Éditions Blanche y las ediciones 00h00. Están especializadas en literatura erótica y le dedican una cuidada atención a las escritoras de Eros. Blanche y $00 \mathrm{H} 00$ publicaron en 1999 varias antologías en las que reunieron a las escritoras más representativas del género y de nuestra época: Désirs de femmes, Françoise Allain, Marie Bornan, Lucie de Boutiny, Sophie Cadalen, Laure Clergerie, Anne-Lise David, Jeanne Decize, Marie-Laure Dougnac, Florence Dugas, Marie L. , Michèle Larue, Sandrine Le Coustumer, Chloë des Lysses, Olivia Paule, Françoise Rey, Astrid Schilling, Julia Vincent; Passions de femmes, Jeanne de Berg, Lucie de Boutigny, Muriel Cerf, Madeleine Chapsal, Marie-Laure Dougnac, Florence Dugas, Marie Gray, Michèle Larue, Chlarisse Nicoïdski, Françoise Rey, Alina Reyes, Sonia Rykiel, Astrid Schilling; Plaisirs de femmes, Marie Bornan, Lucie de Boutigny, Sophie Cadalen, Anne-Lise David, Marie-Laure Dougnac, Florence Dugas, Marie Gray, Léa Khan, Karine Keller, Michèle Larue, Chloë des Lysses, Marie-Jeanne Marti, Nadine Monfils, Françoise Rey, Alina Reyes, Sonia Rykiel, Astrid Schilling, Julia Vincent, Claire Yeniden.

${ }^{5}$ En la última entrega de su Anthologie de récits érotiques, De l'infini au zéro (Paris, Stock, 2000), J.-J. Pauvert señala que se estaría alcanzando un "grado cero de la escritura erótica", por una excesiva producción, gran parte de la cual es de factura femenina.
} 
erótica: aparece un tipo de literatura más práctico que se aproxima a la especie del manual de auto-ayuda relacionado con cuestiones sexuales y dirigidas explícitamente a las lectoras femeninas. Los ejemplos abundan, y las temáticas no. Sirvan de ejemplos estos títulos: 203 façons de rendre fou un homme au lit, Julie de Saint-Ange (1996), de esta misma autora, 302 techniques avancées pour rendre fou un homme (2003), o 208 nouvelles façons de rendre un homme fou de désir, Margot de Saint-loup (2001) y en estos días de marzo de 2004, La Musardine inaugura una colección inédita, Osez, siguiendo en la línea editorial de la casa especializada en letras eróticas, pero en este caso dando cabida a consejos puntuales sobre prácticas sexuales específicas: Osez... les jeux érotiques de D. Saint-Lambert, Osez... l'échangisme de Hélène Barbe .

Este mismo fenómeno de traslación se observa en la literatura femenina en general, de forma que junto a una escritura erótica de mujeres, proliferan obras que llamaremos de "género doméstico", escritas indistintamente por hombres o mujeres, o por los dos a la limón, pero siempre en claves profemeninas: por ejemplo, Pourquoi les hommes n'écoutent-ils jamais rien? Pourquoi les femmes ne savent pas lire les cartes routières?, Barbara y Allan Pease (1999), Pourquoi les hommes mentent-ils et les femmes pleurentelles?, Barbara Pease (2003), Le Sexe des larmes: pourquoi les femmes pleurent plus et mieux que les hommes?, Patrick Lemoine (2003), Lettre ouverte aux hommes qui ne comprennent toujours pas les femmes, Maryse Wolinski (1993), o también, Les femmes et leur plaisir, Isabelle Yhuel $(2001)^{6}$. Es decir, una "prosa" que se situaría entre la autoayuda y los consejos terapéuticos, cuyo leit motiv gira en torno a la materia sexual como elemento regulador de relaciones - desequilibradas siempre- entre hombre y mujer, y sobre sí mismo, que se ofertan como una guía de uso para explicar y enseñar a unas y a otros, no tanto a vivir desde sus naturales diferencias como a limar cualquier diversidad, al margen de sus diferencias o insuficiencias, suplantando el modelo sexista por un planteamiento pseudogenérico, a menudo reduccionista y por ende tan excluyente como el primero. En ambos casos, la vulgarización de lo erótico y la simplificación de lo femenino, como mera pulsión lo primero y como visión doliente y victimista lo segundo, ponen de manifiesto una percepción de la mujer y de lo femenino de baja intensidad que sigue rigiendo no pocos modelos éticos y estéticos en la sociedad de la sobremodernidad.

La escritura erótica femenina presenta un panorama editorial fuerte, al menos en términos cuantitativos, y se declina de forma prioritaria en los géneros narrativos tradicionales (novela, novela autobiográfica, novela epistolar y cuento), o en textos divulgativos. La excepción recae en esta ocasión en el relato en imagen: en el cómic erótico escasea la autoría femenina, tanto dibujante como guionista ${ }^{7}$. Desde un punto de vista temático, los distintos tipos de narración declinan varias categorías semánticas: el cuerpo, el sexo, el deseo, el placer, el bien, el mal, el amor, la muerte. La materia de Eros despliega el amplio catálogo de mirada sobre la anatomía, desde la seducción, el erotismo, la pornografía, la sexualidad, la vacuidad y la plétora. El esquema narrativo parte normalmente de una confrontación del Uno (hombre o mujer) frente al Otro (hombre y/o

\footnotetext{
${ }^{6}$ Véase su última novela, Le Bon Sens amoureux, Paris, J.-Cl. Lattès, 2004.

${ }^{7}$ Ana Mirallés es una de estas ilustradoras. Es la dibujante de la serie titulada Djinn (2001-2003), con guiones de Dufaux, y editada por Dargaud.
} 
mujer) que desarrolla el conflicto de la relación de unos y otros, de unas y otras, en relación al cuerpo, como eje de la individualidad para ser, para sentir y para pensar, pensar(se), u olvidar(se), para ver(se) y mirar(se).

Es frecuente que las autoras de relatos eróticos elijan para tratar la materia de Eros la forma autobiográfica. En este sentido, esta conjunción de autobiografía y erotismo de los libros que dicen "se leen sólo de una mano" articula modelos nuevos en el autobiografismo femenino, orientado hacia un menor intimismo y una mayor exteriorización de la discontinuidad, plenamente asumida en la pulsión de Eros hacia la muerte, hacia el impasse del vacío exterior, hacia su singular identidad. Por otra parte, las escritoras viven una especie de urgencia de decir su cuerpo, que supera el estadio de la simple confesión, o de la revelación de una palabra oculta y silenciada. Los nuevos modos de autobiografía femenina que se configuran como memoria viva de la piel y de la carne se combinan a su vez con posiciones más reflexivas e intelectuales que se practican en una ficción femenina que dice abiertamente el deseo de la mujer y transmite la imagen que re-contruye su cuerpo. Estas representaciones superan la tópica subversión de las prohibiciones y acusaciones pecaminosas que recaen sobre su naturaleza - la sensibilidad social y moral actual concede escaso valor a inhibición y desinhibición, a pudor o rubor, replanteando incluso la propia vigencia del voyeurisme. Las escritoras han diseñado un cuerpo-apertura en todo los sentidos, librado en las palabras, libado en la piel sin ningún límite ${ }^{8}$ para imponer y proponer una distanciada comprensión y una objetiva reflexión que precipitan la ruptura de la sólida correlación entre mujer y cuerpo afecta a una servil ascendencia de hembra y carne compactada en un lugar celado por una palabra y por una imagen, territorios de todos y de todo, pero que no siempre fueron de Ella.

En el horizonte de la literatura erótica femenina, y en la perspectiva de las anteriores consideraciones, las dos obras que hemos destacado resultan sino imprescindibles al menos necesarias para aproximarse a los modos y a los mundos de la literatura erótica femenina en general, y al caso francés en particular. Comparten la provocación y el escándalo, que desataron involuntariamente, en parte por adentrarse en un territorio en sí polémico y además muy masculinizado. Por otra parte, siguen provocando cierta reacción cuando se hacen referencias a una u a otra, y además las dos disfrutan de un sustancioso éxito de ventas. Entre las dos se pueden determinar una compleja relación de similitudes y un enjambre de conexiones. La obra de Pauline Réage, Histoire d' $O^{9}$, publicada en la primera mitad del siglo XX, y La Vie sexuelle de Catherine $M,{ }^{10}$ iniciando el siglo XXI, siguen la estela del ensayo de Beauvoir cuyo Deuxième sexe (1949) enunciaba de forma irreversible la nueva conciencia feminista del cuerpo de la mujer en lo metafórico y en lo real. Entre

\footnotetext{
${ }^{8}$ El estudio de las portadas de estas obras pondría de manifiesto no ya la idea de seducción y sus signos de sustitución y de simulacro, sino una representación sobrenaturalista del cuerpo.

${ }^{9}$ Anne Desclos es la verdadera identidad de Dominique Aury, alias Pauline Réage, quien escribió Historia de $O$ como un testimonio de amor hacia su amante, Jean Paulhan, director de la NRF quien decide publicar el relato. Gallimard lo rechaza y Pauvert acepta el manuscrito que sale en junio de 1954. Será el inicio de una espiral de avatares y escándalos. En 1975 es adaptada para la gran pantalla, y por Guido Crepax en viñetas. Ángel López traduce la obra que Tusquets publica en 1983 en la colección de la Sonrisa vertical.
}

${ }^{10}$ El mismo año Jaime Zulaika realiza la traducción para Anagrama. 
Histoire d'O y La Vie Sexuelle de Catherine M. media un nutrido grupo de escritoras verticales, entre las que podemos citar a las siguientes autoras de especial éxito editorial y reconocimiento en las últimas décadas, desde Régine Deforges ${ }^{11}$, Blanche et Lucie (1976) L'érotique des mots (2003), Françoise Rey, Nuit d'encre (1989) - La Gourgandine (2002), Alina Reyes, Le Boucher (1988) - Corps de femme (2002), Virginie Despentes, Baise-moi (1993), hasta Catherine Breillet, Pornocratie $(2004)^{12} \ldots$ Y si la literatura erótica se encamina hacia un nada deseable "grado cero de la expresión erótica", parece atenuar tal afirmación - entre otras obras- la narración de Millet que ajusta su relato a "la experiencia de los límites" donde se escenifica un teatro total de la carne desde un planteamiento estético e intelectual de inusual expresividad erótica en una escritora.

\section{Del nuevo Relato erótico de Millet.}

En la primavera de 2001, un título tórrido incendia París y abrasa librerías y bibliotecas: La Vie sexuelle de Catherine M.. La editorial Seuil, en la colección "Fictions et compagnies", sin sospecharlo -quizá- acababa de introducir en el mercado un auténtico best-seller que tres años después habría vendido más de 600.000 ejemplares, y se traduciría a unas 31 lenguas, el español incluido. A este rotundo lanzamiento, no menos impactante que la propia obra, se suma el texto de Jacques Henric que ha publicado a la sazón sus Légendes de Catherine $M^{13}$. En este relato fotobiográfico, el escritor mezcla fotos y textos, alusivos principalmente al cuerpo desnudo de su compañera a quien lleva retratando desde hace treinta años ${ }^{14}$. En junio de 2002, en la colección de bolsillo "Points", se reimprime la obra de Millet pero en esta edición la autora incorpora un prefacio titulado "El Por qué y El Cómo", publicado por vez primera en la revista $L$ 'Infini $i^{15}$. Esta modificación de formato en el texto constituye una circunstancia nada desdeñable a la hora de encauzar una reflexión en torno a esta obra, y al propio concepto creativo de la autora.

La afamada y notable crítico de arte, Catherine Millet, se convertía al día siguiente de la publicación de su novela en una autora polémica y conocida. Saltaba al estrellato literario y mediático después de haber arrojado la piedra del escándalo en la que en adelante tropiezan todos los que han leído su obra y se interesan por la historia de las mujeres y le escritura erótica. Millet era conocida hasta entonces en el mundo del arte: había fundado en 1972 la prestigiosa revista Art press que dirige aún en la actualidad, ha escrito numerosos ensayos

\footnotetext{
$"$ Ha sido la primera mujer editora de Francia. Dirigió varias casas editoriales: L’Or du temps (1968-1974), Éditions Desforges (1976-1978), Éditions Régine-Desforges (1986), y con su hijo Franck Spengler -actual director de Éditions Blanche-, con quien dirigió las Éditons Ramsay (1990-1992). Publica O m'a dit (1975), entrevista con Pauline Réage acerca de Histoire d'O. Novelista, cronista, guionista, Desforges goza de gran prestigio y ha publicado una importante obra literaria. Es la Presidenta del Jurado del Prix Femina.

${ }^{12}$ Despentes llevó al cine esta obra. Breillat adaptó para la gran pantalla su obra Le Soupirail (1974) que titula Une vraie fille (2000).

${ }^{13}$ Relato publicado en París, en las Éditions Noël, en 2001.

${ }^{14}$ Acaba de publicar la obra titulada, Catherine" M", l'Album, Paris, L'Instantané Éditions, 2004.

15 «Pourquoi et Comment», n 77 (enero de 2002).
} 
sobre arte contemporáneo ${ }^{16}$ y monografías sobre distintos artistas. Cabe destacar su trabajo en torno a Klein, el pintor del vacío ${ }^{17}$, y a Roger Tallon, el primer diseñador galo ${ }^{18}$. Las vanguardias o la reflexión sobre el mundo contemporáneo, casi todo cabe en su mirada: desde el principio se presenta como una mente vigilante, nada ajena al mundo y alerta a sus circunstancias, combativa frente a las ideologías extremistas y defensora activa de la libertad de expresión y de la libertad sexual. No cabe dudar. Intelectual, esteta, rigurosa, y profundamente vinculada al arte, confiesa poseer una "buena memoria visual"19. Sus trabajos lo acreditan y dan pruebas de la potente mirada del artista que se alía a una precisa conciencia especular y a una incontestable maestría fotoscópica. No prescinde de estos elementos en su escritura que se despliega a través de la densidad de la mirada, la agudeza visual y la versatilidad de la materia sobre las que toman cuerpo la narración y una estética extremadamente visual de su primer relato.

La vida sexual de Catherine $M$. no es un título retórico sino augural y premonitorio: autora-narradora y protagonista, la Millet declina durante más de 200 páginas la crónica de su agitada y copiosa vida sexual. Relata su experiencia del sexo en cuatro capítulos "El número", "El espacio", "El espacio replegado" y "Detalles"20 a lo largo de los cuales su anatomía y numerosas otras, anónimas, conocidas, sin interés, en grupo, o individualmente, buscan y hallan placer, fortuito, a veces organizado, en cualquier lugar y en todos los espacios: bosques, cuarto del conserje, despachos, coches... Ni el medio ni el fin interesan a esta mujer de cuerpo disponible, mente flexible y mirada persistente, sino desear el deseo, complacerse en el placer mediato, compartirlo, y sobre todo distribuirlo, a propios y extraños, ajena a limitaciones ética, física, moral o social, y naturalmente, desprovista de casuística moral, amorosa o sentimental. No se detiene en relatar ninguna espera y ninguna ausencia del amado, no intervienen ni alma ni aporías, sólo el cuerpo, sus miserias y sus grandezas. Desde la infancia hasta la madurez, el relato conciso de su singular práctica sexual y la estrecha habitación de su cuerpo se combinan con una crónica de la memoria de la carne que entremezcla sueños, fantasías y una densa realidad que nutre una anatomía perfectamente diseñada en el territorio de la conciencia y adherente a una voluntad transparente en relación al placer.

En su relato asoma inevitable la experta en arte contemporáneo que administra los intertextos y los espacios de la narradora con reminiscencias del abject art, del body art, de la performance, sin olvidar la nueva carne. El minimalismo de una expresión desprovista de cualquier afectación y retórica sensiblera se harmoniza con la natural descripción de la mecánica sexual y la sensual visualización de una anatomía erotizada cuya mayor desnudez consiste en una persecución casi sin fin, y casi sagrada de la mínima expresión, la máxima

\footnotetext{
${ }^{16}$ Textes sur l'art conceptuel (1972), L'Art contemporain en France (1987) o L'Art contemporain (1997), entre otros textos.

${ }^{17}$ Yves Klein, Paris, Flammarion, 1982.

${ }^{18}$ Roger Tallon, designer, Paris, Éditions du Centre Georges-Pompidou, 1993.

${ }^{19}$ Naturalmente abundan las referencias al espacio visual: la memoria, el ojo-guía, el objetivo de la cámara, pero también la ceguera. Véase Millet, La vie sexuelle de Catherine M., op. cit., p. VIII, pp. 33 y 170.

20 "Le nombre", "L’espace", "L’espace replié", "Détails" son los títulos originales.
} 
sensación y la visión más contundente. Es un cuadro gran formato de vacíos sustanciales y mínimos cromáticos, sin menoscabo de una rigurosa perspectiva, firmado con nombre de mujer cuya mayor protección es la mayor desnudez ${ }^{21}$.

Provocación y escándalo con respecto al relato de Millet no dejan de sorprender en una época de exhibicionismo y voyeurisme exacerbados, de movilización individual y colectiva sobre el cuerpo, ensañada en desdibujar los límites entre erotismo y pornografía, en aras de un visionado de la más obscena cotidianidad ${ }^{22}$. Se ha pretendido reducir este "Relato" a una lista de escenas más o menos truculentas, y a un listado repetitivo de hazañas sexuales, de las cuales la propia autora destaca su inclinación por las orgías y por la multiplicación de los cuerpos en su cuerpo. Por otro lado, quizá el mayor escándalo frente a la obra no radique tanto en el sulfuroso contenido y su presunta exigua calidad literaria, como en una suerte de nostalgia de una escritura erótica más velada, y sobre todo veladora de un secuestro del cuerpo femenino, de su relato y de sus ficciones. En ambos casos, la aproximación resulta simplista y reducionista para un texto que apunta desde el relato y su narración propuestas estéticas que pueden evidenciar un formato novedoso en la literatura erótica femenina:

1- Por un lado, la autora no reproduce el modelo erótico del seductor o de la seductora, tan común en la prosa erótica de firma masculina. De hecho la Millet no es una seductora ni gusta de seducciones ${ }^{23}$. Ella no cree en el signo ni en la panoplia de las apariencias ${ }^{24}$. Obvia el recorrido perverso del seductor deseoso de atrapar al otro, y captar la piel como sustancia de sus operaciones y alimento para nutrir no tanto su individualidad, como su sociabilidad y la visibilidad de su poder. Millet genera una autorreferencialidad inédita que se opone tanto a la trampa de la seducción como al espejismo de lo virtual, e incluso al hiperrealismo de los reality show o loft story con lo que se le ha relacionado ${ }^{25}$. De cierto modo, el relato de Millet es una obra de la anti-seducción, pues el objetivo último es la identidad orgánica del cuerpo, un distanciamiento frente a la propia piel. Inédita también su narración al tratarse de una mujer tan usualmente asimilada a su incapacidad de vencer su dependencia de la piel. El relato de Réage, sin embargo, al cual hace varias referencias, perpetúa la suma de estas dependencias, si bien lo asume y lo elige desde la propia voluntad. Para la protagonista $\mathrm{O}$ la mayor libertad radica en su elección de la cadena, siendo la cadena un mero instrumento anecdótico ${ }^{26}$.

\footnotetext{
${ }^{21}$ Véase Millet, La vie sexuelle de Catherine M., op. cit., p. 55.

${ }^{22}$ Ilustrado con la era del reality show, del loft story, y todos aquellos espectáculos mediáticos, donde el medio deja de ser el filtro para convertirse no ya en mediación sino en el lugar de ubicación primera de la realidad. La pantalla líquida es el nuevo cristalino para formatear lo real

${ }^{23}$ Da a conocer su indiferencia a las "maniobras de la seducción del hombre", señala también su rechazo de "consideraciones sentimentales" (IV), como tampoco pretende alcanzar ni siquiera rozar a los interlocutores cuando habla o escribe sobre el sexo. Véase Millet, La vie sexuelle de Catherine M., op. cit., p. IV, V y 50.

${ }^{24}$ Véase el artículo de Jean Baudrillard, "L’Élevage de poussière », Libération (29 de mayo 2001).

${ }^{25}$ Ibídem.

${ }^{26}$ Véase P. Réage, Histoire d'O, op. cit., p. 55.
} 
2- Por otro lado, en su relato Millet logra desahuciar la mirada del otro como constructor de la identidad ajena: si el cuerpo femenino es generoso y a todos los miembros es receptivo, y siguiendo a Juvenal en su sátira, la mujer puede cansarse pero no saciarse, la Millet le da la vuelta a la antigua y persistente identificación entre mujer y furor uterino, entre hembra y pecado, entre mujer y mal, para en su lugar imponer simple y llanamente la identidad libre que expresa el cuerpo y el deseo en la palabra nueva, tan dispuesta al mundo, al otro y a sí mismo. La palabra de la mujer es una, singular, para contar todas las experiencias que no son nuevas en absoluta, y las preceden una praxis amatoria cuyas delicias y complejidades recogen los textos clásicos del ars amandi $i^{27}$. Lo novedoso y lo percutante radican en la palabra y sobre todo en la voz que dice lo indecible por parte de la mujer, lo prohibido incluso, que se inscribe en un cuerpo del que se distancia y es capaz de contemplar desde el observatorio de la conciencia y el laboratorio de la mente. En el hiato que se crea entre este nivel de mirada intelectualizada y el propio acontecer del cuerpo, surgen las imágenes de sí misma en su total desnudez, que es lo más cercano a la voluptuosa sensación de libertad y total determinación que cristalizan en la toma de palabra, y en un posterior relato. Lo complejo no estriba en el hacer, como en decir sin abismarse en el vacío que separa la representación cada vez más detallada del cuerpo y una conciencia cada vez más disociada del plano mismo de la anatomía. El relato, el placer y el sexo ocupan cualquier vacuidad. Así lo cuenta Millet $^{28}$.

3- Finalmente, en un plano estrictamente formal, la autora confunde desde el propio género de la escritura. Si una lectura precipitada, y la de algunos de sus críticos lo habrá sido al concluir que esta obra resulta inclasificable - tal vez haya que analizar más detenidamente la propia confusión que produce la lectura del texto en cuestión-, señalando que no alcanza en ningún caso el rango de literatura, ni de novela. En efecto, otro de los aspectos inesperados de esta obra es su propia mezcla poética si bien el subtítulo resulta esclarecedor: se trata de un "relato", es decir una relación narrada, y en este caso una fornida relación de historias eróticas que acontecen en su propio cuerpo y en su propia palabra. Combina narración y autobiografía cuya materia no traiciona los habituales contenidos femeninos ni el tradicional tratamiento introspectivo dirigido a la confidencia íntima, a la revelación del secreto, o a la evocación velada de la palabra privada: Millet escribe su historia obedeciendo al deseo de escribir, entendida la escritura como una

\footnotetext{
${ }^{27}$ El Cantar de los cantares, el Kama Sutra, los Tantras, los tratados eróticos de los Vedas, los Upanishads el Arte de Amar, la poesía de Safo serían algunos de estos textos de referencia.

${ }^{28}$ «Plus je détaille mon corps et mes actes et plus je me détache de moi-même», Millet, La vie sexuelle de Catherine M., op. cit., p. 197.
} 
pulsión primaria ajena al resto, una suerte de cavidad que toda alberga después, un especie de cuerpo hueco que irá rellenando "como se pueda" ${ }^{29}$.

En este sentido, Millet en su conmocionante relato otorga una voz grave, clara y timbrada que elimina cualquier vibrato indeseable: así no existe la tesitura del pecado - y bien que lo celebra su compañero: "una mujer sin conciencia de pecado es un auténtico regalo para un creador" ${ }^{30}$. Y en lugar del yermo moral y vacíos estéticos que supondría, ella activa un proceso continuo de "llenado" desencadenado por una pulsión de plenitud, entendida como un cuerpo vaciado que se llena de vacío, y el cuerpo da paso a un sexo "invadido del vacío" 31 , oxímoron clásico de la sacerdotisa moderna de Eros cuyas palabras lubrican no tanto los resortes de la carne como una mirada mecánica y precisa que dirige sobre el mundo y cuya imagen traspasa la retina. A menudo a su confesión y al relato del acontecer del individuo le substituye una prosa ensayística que reduce a su mínimo grado el relato erótico de la mujer y de la carne. Muchos no han dudado en reprocharle su frialdad, su intelectualismo, intelectualidad de la que por otra parte no reniega, por su propia profesión y su curiosidad natural. Y el formalismo en el que se ratifica, se confirma en su praxis escritural. Resulta pues relevante que la escritora adopte y maneje sin falla y pulcritud un lenguaje tan descriptivo y reflexivo para relatar sus prácticas amatorias. Por otro lado, en relación con el polimorfismo poético, Millet, que acaba de publicar en Stock (2003) una reinterpretación del cuento de Perrault, Riquet à la houppe/ Millet à la Houpe, declaró que no dudaba en asimilar su relato con el "cuento" por su capacidad de distanciamiento con la materia narrada de la que logra desprenderse totalmente en el tiempo, de forma que bien podía haber empezado por "érase una vez Catherine M..." Asimismo son constantes las referencias a las artes escenográficas y visuales que constituyen una presencia recurrente tanto en los frecuentes intertextos como abundantes alusiones a la imagen fílmica, fotográfica, escénica ${ }^{33}$. Millet muestra una extremada atención al ángulo de la visión y a la calidad de la mirada a las que la experta en arte no se resiste, y que la erotómana asume y persigue plenamente: en ambos casos, observar para conocer, para decir, para sentir. Imponiendo por tanto un planteamiento estético en su relación con el cuerpo, el suyo y el de los demás, y su voluntad doblemente especular, por

29 «Pourquoi ais-je écris ce livre ? Parce que je voulais écrire et parce qu'il y a des choses dont je ne parle pas. Le désir d'écrire est une pulsion qui se manifeste avant de trouver son objet et qu'on satisfait ensuite comme on peut», Ibídem, p. III.

${ }^{30}$ «Une femme libre, sans culpabilité, est un joli cadeau pour un romancier», J. Henric, Légendes de Catherine M., op. cit., p. 12.

${ }^{31}$ Ibídem, p. 228.

${ }^{32}$ Véase la entrevista «Livres», Le Nouvel Observateur, n² 2013 (5 junio 2003).

${ }^{33}$ En noviembre de 2003, Jacques Malaterre adaptó el texto de Millet para la escena. Marie Matheron interpretó a la Millet, en el escenario del Théâtre Fontaine de París. Por otra parte, las referencias al espacio dramático, fílmico y fotográfico son recurrentes: la técnica del guión, el escenario, el ángulo fílmico, los tránsitos de la cámara, las alusiones directas al mundo del cine (por ejemplo, Piccoli o Godard). Siempre le interesa relacionar el espacio del cuerpo con el espacio visual, fílmico, fotográfico. Se extiende en estos elementos en el último capítulo, "Détails", y concluye su relato con el apartado "Visionnages", es decir, con el juego de la cámara sobre el cuerpo, sobre su cuerpo. 
las imágenes y por las preguntas, hasta lograr que se refracten cuerpo y conciencia pero que coincidan cuerpo real y sus imágenes ${ }^{34}$.

La ascesis resultante de la escritura linear, casi flaubertiana, que traza la Millet al manejar la pluma como un escalpelo, diseccionando ${ }^{35}$ una realidad que es la suya y suyas también las claves interiores, que percibe y describe con la misma exactitud con la que maneja las exteriores. Supera la tentación de la metáfora, ha exiliado cualquier huella de intimismo, no incluye el espacio de diario -ella misma indica que nunca escribió ningún-, explica por el contrario que se ha basado en observaciones y anotaciones, siguiendo el procedimiento que utiliza en la crítica de $\operatorname{arte}^{36}$. No realiza ninguna concesión en la aprehensión del objeto contemplado - que es su propia vida sexual-, ni tampoco a la hora de delimitar el objeto, observarlo, describirlo, analizarlo, sin delirios ficcionales y en casi completa ausencia novelesca - exceptuando un cierto pintoresquismo en alguna descripción erótica-. Estos apuntes biográficos, de sorprendente privacidad revelan por el contrario una cerebralidad desconcertante para un lector que presencia una carnalidad masiva casi proporcional al grado de penetración y libramiento de su vida íntima, tanto en la descripción de su vida sexual, sus principios y reflexiones al respecto, como al internarse en su memoria, en su infancia, y sus padres que constituyen junto al hombre con quien comparte su vida, su profesión y sus revelaciones, los espacios más sensibles de su confidencialidad. Las notas tomadas servirán para el ensamblaje final de las piezas, perfectamente hilvanadas, en una superficie lisa, frente a la propensión discursiva y el volumen confesional características de la palabra femenina y de sus transcriptoras.

Millet apura la realidad, al límite de lo referencial, la depura casi hacia una realidad de diseño, elaborada, revisitada, estéticamente correcta, pero siguiendo su voluntad sin pactar con "la instancia social": el texto, la obra están por encima de la autora y de la doxa $a^{37}$. Aunque en este punto en la autora y en el personaje podemos detectar una contradicción: frente a esta reivindicación de la palabra detrás de la cual han de desdibujarse el personaje y la autoría, la escritora acaba por hacer una concesión y la mujer de algún modo, claudica. Cuando incorpora el prefacio "El Por qué y el Cómo". Y cabe preguntar acerca de las razones que han motivo una voluntad explicativa y una acción justificativa. ¿Por qué explicar? ¿Por qué entregar ahora esta "Vida sexual de Catherine M., modo de uso?”. ¿Para esclarecer más, para justificarse, justificar procedimientos? ¿Para evitar lo inevitable, lo impensable, lo incomprensible? Estas preguntas y sus respuestas han horadado el lecho milimetrado de la escritura de Millet, es una paisaje desviado en una travesía tan recta y tan libre. La escritora es ahora mujer reconducida, seducida por el modelo logocéntrico que exige no tanto proporcionar el guión previo como el acta sentenciosa de la confesión. Esta sorprendente captatio benevolentia, de término posterior,

\footnotetext{
${ }^{34}$ Señala precisamente, al término de su relato, que al fin ella sabe de la plenitud y de "la coïncidence de mon corps vrai et de ses multiples images volatiles", Millet, La vie sexuelle de Catherine M., op. cit., p. 234.

${ }^{35}$ Baudrillard en su artículo de Libération (mayo 2001) hace referencia a esa «obscenidad radical de Catherine Millet», según él otro caso, al igual que el loft story show, de realidad experimental, otro tipo de "vivisección", donde disección sexual y social se funde en una misma visibilidad estéril y mecánica.

${ }^{36}$ Millet, La vie sexuelle de Castherine M., op. cit., pp. VII-VIII.

${ }^{37}$ Ibídem, pp. IX-X.
} 
convoca justo la instancia social que Millet repudió en todo momento tanto en su conducta social, en sus prácticas sexuales y su relato, como en su carrera profesional - por otro lado, $\tan$ interrelacionadas-. La duda en torno a los motivos crece tanto más cuanto que las Leyendas de Jacques Henric han sido publicadas en el mismo tiempo y por tanto matizan su recorrido vital y completan su relato biográfico, a través de esta fotobiografía no menos singular y tanto más voluptuosa cuanto que el fotógrafo-escritor se esmera en una perspectiva más contemplativa, íntima e intimista, narrando a la amada utilizando su personal álbum de desnudos y bellísimos textos con los que pauta los relatos sobre Catherine M.. Precisa las narraciones entrecruzadas, engarzados cuerpos y vidas, imágenes y palabras, memoria y espacio, entregando otras claves de una creación que se nutre de esta aproximación a la amada, de su singular relación de la mujer a su cuerpo, a su palabra y al propio objeto artístico que emana de esta relación. Bien es cierto, por otro lado, que el prefacio algo atemporal que decide introducir la autora no contrarresta el efecto del relato erótico ni tampoco invalida el dinamismo y la renovación que ha supuesto Catherine Millet en el horizonte de la literatura erótica, y de la femenina en particular.

\section{De LA ESTÉTICA DE LA PLENITUd EN LA ESCRITURA ERótiCA DE MILLET.}

Frente a una común representación de la mujer descrita en escenas eróticas, que se asocia a la imagen del lazo, del cordón, de la cadena, del hilo, desde el hilo del telar de Penélope, los hilos discursivos de la fabuladora Sherezade hasta las cadenas de O y las cuerdas del cuerpo de Guliver en las que sueña ${ }^{38}$, se entreteje una red que las rodea, las envuelve y las ata anillada a un cuerpo narrado y visitado por el Otro, Millet - sin renunciar a la imagen de las "cadenas del placer" 39 - por otra parte propone una estética de lo lleno y de la plenitud, indisociable del imperativo del vacío que convoca el lugar del cuerpo, el hueco sustancial que dimensiona espacio y tiempos.

A esta búsqueda de plenitud corresponde un proceso de completud que se traduce en la sintaxis narrativa por conexiones discursivas y representaciones simbólicas correspondientes a un dispositivo escritural que suma elementos anecdóticos y formales como el intercambio de cuerpos seriados, amalgamados en la carne de la mujer siempre disponible y entregada al azar. Todo espacio está siempre hueco, hasta ser ocupado por el cuerpo. Por otro lodo, escasean las muestras de debilidad, salvo en contados casos como los episodios relativos a los celos y a su pareja ${ }^{40}$. Tampoco abundan lugares de confusión: ni siquiera en los relatos orgiásticos, la dispersión que supone el sexo colectivo conduce, paradójicamente a una organicidad plena y completa, que activa asimismo una imparable voluntad de postración y un autorretrato donde narcisismo y soledad detienen rupturas, fisuras y fragmentos, organizándose esta fruición universal del deseo, una inquebrantable voluntad de desear y una capacidad ininterrumpida de entrega. En este sentido, Millet sin traba y sin tregua, entrega su anatomía-vacancia, "a una invasión del vacío" por parte del

\footnotetext{
${ }^{38}$ P. Réage, Histoire d'O, op. cit., p. 197.

${ }^{39}$ Se trata de "les chaînes ouvrières du plaisir", Millet, La vie sexuelle de Catherine M., op. cit., p. 221.

${ }^{40}$ Ibídem, p. 77.
} 
otro $^{41}$. Pero rechaza cualquier tipo de sumisión y explica que su "docilidad sólo se explica por su indiferencia al uso que se hace de los cuerpos" ${ }^{\prime 4}$; contrariamente a la obra de Pauline Réage cuyo relato se dedica a narrar la aceptación, y se desarrolla en torno al consentimiento de la amante a la sumisión como acto único de voluntad-.

En la obra de Millet, la vacancia, el vacío, la anatomía sólo se configuran como una desnudez, carente de signos, ofertada al mundo, sin transacción, sin plazos ni deudas, en su entera vacuidad, disponible una vez más, desde sí mismo para el Otro. Esta relación con el cuerpo sin interrupciones morales ni fisiológicas se suma a una relación de conciencia ante la anatomía, conducente a un posicionamiento del individuo frente a los cuerpos ajenos, frente al continuum exterior. Plenitud anunciada desde un principio por la joven visitadora de sexos en grupo; narcisismo y soledad constituyen además dos puntales para sostener un edificio intelectual que reposa sobre la esencial fragilidad del cuerpo y de sus humores, y su irrenunciable fruición. Por otro lado, la protagonista oscila de la "soledad paradójica" a una "voluptuosidad de la soledad" ${ }^{43}$ que expresa la división entre su inclinación por la pluralidad de cuerpos y el placer de la soledad del propio cuerpo, la cadena universal del placer y la fractura que impone la voluntad individual y solitaria. La "soledad paradójica" que la narradora-protagonista confiesa vivir y disfrutar ${ }^{44}$ no sólo no la encadena a los espacios de melancolía o de nostalgia sino que de nuevo constituye una vía para cultivar los saberes, para experimentar, y ponerse a prueba. Pero este laboratorio encarnado no se limita a lo experimental sino que traspasa el plano mórbido de la imagen y de la carnalidad para trasvasarse hacia la palabra, y así disponerse a relatar lo inenarrable. Y el relato de su sexo no lo asume en absoluto como un acto de valor, ni siquiera de subversión: es un acto de conciencia, de perseverancia, laborioso - además escribir supone un ejercicio de tenacidad y perfeccionamiento muy especial aún más en la escritura erótica en la que lo obsceno y lo vulgar acechan al escritor de un modo más acuciante ${ }^{45}$, y una toma de decisión que conlleva desde la disponibilidad, antes mencionado, una completa permisividad, y ninguna coerción frente al sexo, impulsando su "incansable conquista" y "la ilusión de

\footnotetext{
${ }^{41}$ Vacancia y disponibilidad en el cuerpo y en la conciencia que la definen sin ambigüedad desde el principio, y desde sus inicios como una mujer "vacante" dispuesta y cumplidora de las tareas que le son encomendadas: su entrega era ejemplar y completa. Véase Millet, La vie sexuelle de Catherine M., op. cit., pp. 32, 46, 214 y 228.

42 "Je suis docile non par goût de la soumission, car je n'ai jamais cherché à me mettre dans une position masochiste, mais par indifférence, au fond, à l'usage qu'on fait des corps ", Ibídem, p. 214.

${ }^{43}$ Ibídem, pp. 48 y 93 respectivamente.

${ }^{44}$ Ibídem, p. 48.

${ }^{45}$ Millet no emite ningún juicio moral sino una exigencia profesional de elegir las palabras para que su relato evite contaminarse tanto de lo afectivo como de lo vulgar e impreciso: se trata de dar a conocer una verdad de su vida por lo que resulta imprescindible que el intercambio verbal sea lo más riguroso y certero posible, por un lado para evitar "tocar al interlocutor en su instinto sexual "y por otro lado para alcanzar su objetivo: "decir una verdad que es un testimonio de sí misma", Ibídem, pp. IV-IX.
} 
posibilidades oceánicas"46. Al final su decisión de relatar el sexo equivale a "elaborar un texto de verdad, la verdad de un ser singular" ${ }^{\prime 47}$.

Y si el sexo se llena y se completa, lo esencial no radica tanto en el abrumador criterio cuantitativo - tan propio del seductor y tan penado para las mujeres, pero tan nuevo en el relato femenino del sexo- como en la consideración espacial - no en vano inspira los títulos de sus distintos capítulos- siendo por excelencia el cuerpo el real lugar, los límites certeros que nos circundan, nos entierran y nos arrojan al mundo, por tanto la anatomía y el sexo emergen como el lugar, el otro lugar de otra vida, y el lugar de otro relato. Por ello poco importa la identidad de los habitantes de estos cuerpos, pues ella "manipula su cuerpo como el marionetista su marioneta"48 - impone el regreso al hombre-máquina -siempre "apto al placer" señala Millet ${ }^{49}$, sin lubricante ni afectos, desde los niveles más preclaros de la conciencia para ejecutar el proceso, ensamblar las piezas que organizan los territorio de los efectos sensoriales, paisaje del deseo que reverbera en renovados impulsos eróticos, aunque el máximo placer a veces sólo radique en la perfecta articulación de la mécanica anatómica y la exacta ejecución del procedimiento físico, y "el cumplimiento del ritual"s0.

Estética de la plenitud que se basa pues en una búsqueda del placer, vivida como una urgencia de ser, sin tregua, sin trampas, urgencia también de decir la verdad por parte de un ser singular y así lo indica la propia Millet desde el principio ${ }^{51}$. Esa búsqueda del placer en una cosmogonía azarosa, sin embargo obedece a una decisión tomada, siendo el objetivo último completar el recorrido anatómico y sexual que conlleva la expresión de ser en el cuerpo y para otros cuerpos, un posicionamiento rotundo desde la carne, desde el umbral más frágil y vulnerable del individuo y para la comunidad. Intercambio de sexos, de fluidos, y divulgación de estos intercambios, para dar a conocer esta red encarnada de la vida, pero sin confusiones, ni de lenguajes ni de saberes: es una opción estética y ética ${ }^{52}$. Este gozoso planteamiento de la Millet en el que tanto en la práctica de su sexualidad como en la propia articulación erótica del discurso y de la narración se ponen de manifiesto una absoluta voluntad y una asunción del cuerpo como materia del ser, y se contrapone a un cierto victimismo y alienante postura proteccionista frente al otro que vehicula determinada ideología feminista más presta a denunciar sólo que a enunciar. Cuando precisamente en la escritura erótica de Millet, la disponibilidad de la autora-narradora-protagonista se constituye no como un acto de sumisión al Otro sino como una transacción hacia el objeto

\footnotetext{
${ }^{46}$ Este modo de vida volcado en el sexo -ecléctico y extenso- le proporciona en efecto "l'illusion d'ouvrir en [elle] moi des possibilités océaniques»), Ibídem, p. 69.

${ }^{47}$ Ibídem, p. X.

${ }^{48}$ Ibídem, p. 211.

${ }^{49}$ Ibídem, p. 172.

${ }^{50}$ Ibídem, p. 172.

51 "La vie sexuelle de Catherine M. se veut avant tout un témoignage, c'est-à-dire, à proprement parler, un texte destiné à établir une vérité, la vérité d'un être singulier, bien sûr », Ibidem, p. IX. Idea que retoma en varias ocasiones, insistiendo sobre la necesidad de « decir la verdad de todo esto», Ibídem, p. 93.
}

52 Para Millet, en las redes sociales, grupos profesionales y comunidades de cuerpos se superponen sociabilidad y sexualidad, multitud y cadenas de individuos, en cuyo seno se desarrolla la paradójica soledad que la caracteriza. 
que aún no está, desde esta vacancia que precede el objeto que no es, desde la vacuidad de la anatomía, la plenitud de la conciencia, y la voluntad de desear y de activar su proceso superan la simple consecución del placer. El resultado último importa en tanto parte del proceso que ha de desarrollarse y concluir, pues en esta culminación de la tarea se cristaliza parte de la identidad libre del hombre y de la mujer en sí mismo.

La estética de la plenitud desemboca precisamente en una poética de la palabra, el otro lugar en el que se cobijan las figuras, y que junto a la imagen constituyen los elementos claves para el relato y detienen un singular poder en la literatura erótica. Por su doble condición de experta en arte y de escritora, Catherine Millet alude muy justamente al "placer de contar, de narrar" 53 . Se sitúa por otro lado en la tradición literaria más remota que asocia el relato a la propia identidad del hombre, una de su disposición, al mismo título que el placer sexual. Millet recupera así la tendencia natural del individuo a contar, y encarna un papel antiguo, la función de cuenta-cuentos, pero contrariamente al personaje de $\mathrm{O}$, que también se autodenomina Sherezade ${ }^{54}$, Millet no quiere diferir nada, ni los planos discursivos, ni los reales, elle no vive en los aplazamientos de la seducción, ni en los intersticios de las apariencias, que no le interesan e incluso desprecia, sino en la inquietante erotización y la celebración sexual de la voluntad que se completa en tanto se consuma el proceso, ininterrumpidamente de cuerpo a cuerpo, de voluntad a decisión, de decisión a ejecución.

En esta perspectiva, Catherine Millet plantea una inversión de la tradición que ha consagrado la relación entre la mujer y la palabra, y en este sentido invita a una revisión de la misma. No se trata de contar su singular historia para provocar, transgredir, ni siquiera excitar al otro -aspecto que muchos consideran como criterio único para definir el género erótico-, sino precisamente desde la plenitud creativa, del mismo modo que ella expresa su deseo de "ampliar el espacio", de llenar el vacío, por definición vacío 55 , anulando eso sí cualquier misterio del cuerpo, plenamente referenciado como espacio único y último, y deshaciendo así también el fundamento de la seducción cuyo destino fatal se transcribe en las apariencias que colmatan al hombre en una voluntad más blanda y redondeada, más propia de una sensibilidad barroca o clásica, que no de un planteamiento extremadamente contemporáneo, sin fisura, mínimo pero rotundo, monocromo casi como las telas de Klein. Millet se ocupa a través de la palabra de ceñir ese objeto por crear, por decir, es el vacío por colmar, el lugar exacto por llenar: desde el cuerpo, y luego vencida la fícción, en la palabra se inicia el relato que tanto ella desea, el otro relato, sin reservas ni prebendas.

\footnotetext{
53 Millet elabora una poética de la plenitud que se desarrolla entre "el placer de contar" y "el relato de placer", Millet, La vie sexuelle de Catherine M., op. cit., pp. 69-84 y 222-230.

${ }^{54}$ P. Réage, $O m^{\prime}$ 'a dit, op. cit., p. 101.

55 Esta conquista del espacio se fragua en el descubrimiento del cuerpo que adquiere fuera de los espacios cotidianos, pues explica Millet que las estrecheces de su infancia la llevaron a asimilar "espacio exiguo" y "espacio lleno" y a huir de los mismos, para ensanchar horizontes. Véase Millet, La vie sexuelle de Catherine M., pp. 130 y 158 .
} 
Y así la palabra será el relato y ella la heroína de una historia escrita por ella ${ }^{56}$, y en ella. Es un nuevo relato, otro discurso, desmarcado del modelo, aunque sin rechazar al modelo. No le interesa la relación mimética con lo otro, sino una aptitud sumamente creativa. Tampoco hallaremos ningún eco militante a favor de la ruptura de modelos masculinos o femeninos o imponer un canon u otro, no son los términos de su escritura, ni los propósitos de su estética. Hasta el punto que en el principio del relato indica que "no está con las mujeres, tampoco en contra de los hombres, sino junto a los hombres", si bien en un segundo término, afirma su "simpatía con sus congéneres",57 y finalmente, en el prefacio antes citado, les dedica su trabajo a las mujeres ${ }^{58}$. Vilipendiada por parte del público y de la crítica, es en realidad la heroína que habita plenamente en la asunción de los lugares que fueron arrebatados en el gineceo, la palabra y la carne. Tiene el propósito deliberado de ser y de decirse, sabe que sólo se es en la palabra y en las imágenes, en los territorios del cuerpo, en los relieves del sexo, en los paisajes del deseo y en los pliegues del placer.

En el relato de Catherine Millet se inscriben el nuevo posicionamiento erótico de la mujer contemporánea, y así también arroja suficiente inquietud como para revisar los textos y la literatura erótica femenina a la luz de esta estética de la plenitud y del placer de la palabra en la mujer. Y si no convencen ni la plétora de sus crónicas anatómicas, ni el sobrenaturalismo, ni el hiperrealismo, ni el materialismo postsadiano, ni siquiera el simple oportunismo editorial, sin embargo no cabe dudar: una vez dicho todo, todo está por hacer, todo está por llenar, rellenar de verdad y de sueños. La escritura erótica femenina de la mano de Catherine Millet no vulnera ninguna mirada ni tampoco la palabra; las replantea todas. Invita a revisar la relación de la mujer con el cuerpo y con la palabra, y a revisitar con la mirada los espacios medianos entre su cuerpo y el relato.

\section{REFERENCIAS BIBLIOGRÁFICAS.}

BARTHES, R., Fragments d'un discours amoureux, Paris, Seuil, 1977.

BATAILLE, G., Érotisme, Paris, Minuit, 1985 (1957)

BAUDRILlard, J., De la Séduction, Paris, Folio, 1988 (1979).

BOREL, Fr., Le Corps-Spectacle, Revue de l'Université de Bruxelles, 1987, 3-4.

BRUCKNER, P. et FINKIELKRAUT, A., Le Nouveau désordre amoureux, Paris, Points, 1977.

CAMPHAUSEN, R., Diccionario de la sexualidad sagrada, Barcelona, José J. De Olañeta, 2001.

\footnotetext{
${ }^{56}$ Destaquemos el singular espíritu novelesco que aparece en algún momento en Millet, y que se relaciona con una terna natural en el personaje, placer, voluntad y destino: "Mon plaisir est dans ce moment précis, quand la decision est prise en moi, que l'autre est un peu pris de court. J'éprouve la sensation enivrante d'accomplir un destin d'héroïne", Ibídem, pp. 48-49.

${ }^{57}$ Ibídem, p. 51.

${ }^{58}$ Ibídem, p. IV y p. 16.
} 
DUBOIS, Ph. et WINKIN, Ph., Rhétoriques du corps, Bruxelles, De Boeck Université Prisme, Texte.Société/ 7, 1988.

DUBY, G.et PERROT, M. (bajo la dir.), Historia de las Mujeres en Occidente, 4 vols., Madrid, Taurus, 1992.

FEELMAN, S., Le Scandale du Corps parlant, Paris, Seuil, 1980.

FEHER, M., NADDAF, R. et TAZI, N. (dir.), Fragmentos para una historia del cuerpo humano, 3 vols., Madrid, Taurus, 1990 (1989).

FOUCAULT, M., Histoire de la Sexualité, 4 vols., Paris, Gallimard, 1971-1984.

GUIRAUD, P., Sémiologie de la sexualité, Paris, Payot, 1978.

GUIRAUD, P., Dictionnaire historique, stylistique, rhétorique, étymologique de la littérature érotique, Paris, Payot, 1978.

HANS M. et LAPOUGE, G., Les Femmes, la Pornographie, l'Érotisme, Paris, Points, 1978.

HENAFF, M., Sade, l'Invention du Corps libertin, Paris, PUF, 1978.

PAUVERT, J.-J., Anthologie Historique des Lectures Érotiques, 3 vol., .De Sade à Fallières (1789-1914), Paris, Garnier, 1982, De Guillaume Apollinaire à Philippe Pétain (19051944), Paris, Ed. Suger, 1987. De Félix Gouin à Emmanuelle, de 1944 à nos jours, Paris, E. Ramsay, 1980.

PAZ, O., La Llama doble. Amor y erotismo, Madrid, Seix Barral, 1994.

PERROT, Ph., Le Travail des apparences. Le corps féminin, Paris, Éditions du Seuil, 1984.

PIA, P. Dictionnaire des Oeuvres Érotiques, Domaines Français, Paris, Mercure de France, 1971.

ROUGEMONT, R. de, Les Mythes de l'amour, Paris, Gallimard, 1961.

ROUGEMONT, R. de, L'Amour et l'Occident, Paris, Plon 1972.

SCHILDER, P., L'Image du corps, Paris, Tel/Gallimard, 1968 (1950).

SIBONY, D., Le Nom et le corps, Paris, Seuil, 1974.

SIBONY, D., L'Amour inconscient. Au-delà du principe de séduction, Paris, Grasset, 1988.

SPADA, M., Érotiques du merveilleux. Fictions brèves de langue française du XXe siècle, Paris, J. Corti, 1983.

VASSE, D., Le Temps du désir, Paris, Seuil, 1966.

VASSE, D., La Chair envisagée. La génération symbolique, Paris, Seuil, 1988. 